\title{
Regional Price Adjustment in a Monetary Union
}

\author{
Jan Marc Berka,b,d \\ Job Swank $k^{a, c}$
}

a The Netherlands Bank, Amsterdam,

b Faculty of Economics and Business Administration, Free University of Amsterdam,

c General Economics, Erasmus University Rotterdam,

dTinbergen Institute. 
Tinbergen Institute

The Tinbergen Institute is the institute for economic research of the Erasmus Universiteit Rotterdam, Universiteit van Amsterdam and

Vrije Universiteit Amsterdam.

Tinbergen I nstitute Amsterdam

Keizersgracht 482

1017 EG Amsterdam

The Netherlands

Tel.: +31.(0)20.5513500

Fax: $\quad+31 .(0) 20.5513555$

Tinbergen Institute Rotterdam

Burg. Oudlaan 50

3062 PA Rotterdam

The Netherlands

Tel.: $\quad+31 .(0) 10.4088900$

Fax: $\quad+31 .(0) 10.4089031$

Most TI discussion papers can be downloaded at

http://www.tinbergen.nl 


\title{
REGIONAL PRICE ADJUSTMENT IN A MONETARY UNION THE CASE OF EMU *
}

\author{
Jan Marc Berk ${ }^{\mathrm{a}, \mathrm{b}}$ and Job Swank ${ }^{\mathrm{a}, \mathrm{c}}$ \\ ${ }^{a}$ The Netherlands Bank, Monetary and Economic Policy Department, P.O. Box 98, \\ $1000 \mathrm{AB}$ Amsterdam, The Netherlands (corresponding address) \\ ${ }^{\mathrm{b}}$ Free University of Amsterdam, Dep. of Economics \& Business Administration \\ ${ }^{\mathrm{c}}$ Erasmus University Rotterdam, Ocfeb Research Centre for Economic Policy
}

\begin{abstract}
Using a New-Keynesian framework, we investigate how far the inflationary processes in member states of EMU cause regional price levels to converge. We fail to produce hard evidence of the present existence of such an adjustment mechanism, notwithstanding that inflation in some countries tends to converge towards the euro area level. Overall, inflation persistence has declined significantly over the years, but there are still marked differences between countries on this score. We conclude that the euro area is not an optimal currency area yet, lending support to the quest for further structural reforms in European labour and product markets.
\end{abstract}

Jel Classification: E31; F02; E58

Keywords: Inflation; EMU; Monetary policy

* Thanks are due to Henk van Kerkhoff for data assistance. The views expressed do not necessarily reflect those of the Netherlands Bank. 


\section{Introduction}

On January 1, 1999, the currencies of eleven member states of Economic and Monetary Union (EMU) became irrevocably fixed. As a consequence, the nominal exchange rate channel as a propagation mechanism of asymmetric shocks within the euro area was shutdown. Since then, mean-reversion of real exchange rates (or international competitiveness) across the euro area relies exclusively on convergence of regional price levels. This paper addresses the empirical question whether or not such convergence is inherent in the inflationary processes of member states, and if so, how fast it occurs.

A related issue is the extent to which price dynamics differ between countries as regards inflation persistence and the pass-through of changes in the real exchange rate and domestic demand pressure. Such heterogeneity may render the common monetary policy conducted by the European Central Bank (ECB) suboptimal for (some) individual countries and is thereby a potential cause of tension among Governing Council members of the ECB (Aksoy et al., 2002). This imposes constraints on fiscal policies, which are still in place to cope with regional inflation divergences. However, differences in national preferences may seriously hamper that kind of accommodating behaviour by sovereign governments (Hughes Hallett and Weymark, 2001), notwithstanding the requirements of the Maastricht Treaty, the Stability \& Growth Pact, and the Broad Economic Policy Guidelines.

Of course, such coordination failure will become less pressing as the real economies of member states of EMU get more integrated. This stresses the importance of completing the Internal Market by ongoing efforts at harmonizing tax and benefit systems across national borders, at structurally reforming labour and product markets, etc. While this is clearly a long-term challenge, some progress has been made during the past two decades, which we try to detect empirically by assessing regional inflation dynamics in the euro area over different time spans. This also allows us to test the proposition put forward by Taylor (2000) and others that the shape of the Phillips curve tends to vary with the inflationary environment. 
Our empirical analysis is embedded in a simple New-Keynesian framework, incorporating inertia - which are commonly seen as characteristic of European labour and product markets (Gonenc et al., 2000) - and forwardlooking behaviour in the determination of inflation. The focus on regional price adjustment within a monetary union is fairly novel, as most of the existing literature on inflation dynamics concentrates on monetarily sovereign countries (e.g., in the context of assessing different strategies of monetary policy). A further innovative aspect of our approach is that we allow and test for convergence of expectations to the rate of inflation in the euro area as a whole. Our evidence on this score is rather tentative, though, due to some restrictive assumptions on expectation formation (especially prior to the establishment of EMU).

The remainder of the paper is organized as follows. The next section contains our conceptual framework, which is put to the test empirically in section 4 , after a discussion of data issues in section 3. Section 5 concludes.

\section{Conceptual framework}

Our starting point is an expectations-augmented Phillips curve as contained in the work of Svensson (1998) and Leitemo and Söderström (2001), with domestic inflation predetermined one period:

$$
\begin{aligned}
& \pi_{\mathrm{t}}=\alpha \pi_{\mathrm{t}-1}+(1-\alpha) \mathrm{E}_{\mathrm{t}-1}\left(\pi_{\mathrm{t}+1}\right)+\beta \mathrm{E}_{\mathrm{t}-1}\left(\mathrm{y}_{\mathrm{t}}\right)+\gamma \mathrm{E}_{\mathrm{t}-1}\left(\mathrm{e}_{\mathrm{t}}\right)+\delta+\varepsilon_{\mathrm{t}} \\
& 0 \leq \alpha \leq 1 ; \beta>0 ; \gamma<0
\end{aligned}
$$

where $\pi_{t}$ is the annualized domestic rate of inflation, measured as the difference of the $(\log )$ gdp-deflator $\left(p_{t}\right), y_{t}$ is the output gap, $e_{t}$ is the $(\log )$ real exchange rate, $\varepsilon_{\mathrm{t}}$ is a white-noise supply shock, and $E$ is an expectations operator. The suffix $t$ indicates the (quarterly) time period. The expectations of $\mathrm{y}_{\mathrm{t}}$ and $\mathrm{e}_{\mathrm{t}}$, formed in period $\mathrm{t}-1$, should be regarded as deviations from their steady-state levels, which are assumed to be constant and to be captured by the intercept $\delta$ for convenience. The real exchange rate is defined as:

$$
\mathrm{e}_{\mathrm{t}}=\mathrm{s}_{\mathrm{t}}+\mathrm{p}_{\mathrm{t}}-\mathrm{p}_{\mathrm{t}}{ }^{*}
$$


where $s_{t}$ is the $(\log )$ spot exchange rate (in units of foreign currency per unit of domestic currency), and $\mathrm{p}_{\mathrm{t}}{ }^{*}$ is the foreign (log) gdp-deflator. The parameters $\alpha, \beta, \gamma$ and $\delta$ may differ across countries. Of course, they may also change over time due to shifts in wage negotiation models, opening-up of product markets (both domestically and across borders), and so on.

For a theoretical underpinning of eq. (1), we refer to Svensson (1998, Appendix C). He derives a macroeconomic supply function from a first-order condition of an optimization problem for an open economy, adding inflation persistence along the lines of Fuhrer and Moore (1995). This last extension gives the equation its 'Keynesian' flavour of price-staggering, which has recently been worked out by Taylor (2000) and Choudri and Hakura (2001) in the context of marginal cost and exchange rate pass-through.

To see what EMU implies, consider the more extreme case in which $\mathrm{s}$ is completely fixed. Then, the real exchange rate in eq. (1) acts as an equilibrating mechanism in that it incites inflation as long as the domestic price level is expected to lag behind the foreign price level (provided, of course, that $\gamma<0) .{ }^{1}$ As a consequence, international price level differences are only temporary. Clearly, it depends on the strength of the real exchange rate channel (i.e., on $\gamma$ ) and on domestic inflation dynamics (notably $\alpha$ ) how long that adjustment process takes. The more integrated and dynamic the real economies of countries are as regards product market competition, wage rate determination and so on, the sooner equilibrium will be restored.

We intend to shed some light on this issue in the context of EMU by estimating eq. (1) for five larger member states. This requires that certain assumptions be made on the formation of expectations about future inflation, the output gap and the real exchange rate. We assume that $y_{t}$ and $e_{t}$ are expected to converge to their constant steady-state levels ( $\overline{\mathrm{y}}$ and $\overline{\mathrm{e}}$ ) according to the adaptive mechanisms:

\footnotetext{
${ }^{1}$ Note that the real exchange rates of member states of EMU (e) are still subject to changes in nominal exchange rates vis-a-vis the currencies of countries outside the euro area.
} 


$$
\begin{array}{ll}
\mathrm{E}_{\mathrm{t}-1}\left(\mathrm{y}_{\mathrm{t}}\right)=\kappa \mathrm{y}_{\mathrm{t}-1}+(1-\kappa) \overline{\mathrm{y}} & (0 \leq \kappa \leq 1) \\
\mathrm{E}_{\mathrm{t}-1}\left(\mathrm{e}_{\mathrm{t}}\right)=\lambda \mathrm{e}_{\mathrm{t}-1}+(1-\lambda) \overline{\mathrm{e}} & (0 \leq \lambda \leq 1)
\end{array}
$$

Note that expectations are static in case $\kappa=\lambda=1 .^{2}$ The expectation of oneperiod ahead inflation in each member state of EMU is assumed to converge to the expectation of one-period ahead inflation in the euro area as a whole, $\mathrm{E}_{\mathrm{t}-1}\left(\Pi_{\mathrm{t}+1}\right)$, according to:

$$
\mathrm{E}_{\mathrm{t}-1}\left(\pi_{\mathrm{t}+1}\right)=\mu \pi_{\mathrm{t}-1}+(1-\mu) \mathrm{E}_{\mathrm{t}-1}\left(\Pi_{\mathrm{t}+1}\right) \quad(0 \leq \mu \leq 1)
$$

This is asymptotically consistent with the aforementioned hypothesis that regional price level differences within EMU tend to disappear in the long run. The persistence coefficients $\kappa, \lambda$ and $\mu$ may differ across countries, just like (or rather in conjunction with) the parameters in eq. (1). Finally, we assume that one-period ahead inflation in the euro area as a whole is expected to converge to the constant rate $\Pi^{*}$, representing the rate of inflation the European (system of) central banks consider(s) to be consistent with mediumterm price stability:

$$
\mathrm{E}_{\mathrm{t}-1}\left(\Pi_{\mathrm{t}+1}\right)=v \Pi_{\mathrm{t}-1}+(1-v) \Pi^{*} \quad(0 \leq v \leq 1)
$$

Upon substituting eqs. (3) to (6) into eq. (1), we arrive at the final estimating form:

$$
\begin{aligned}
& \pi_{\mathrm{t}}=\alpha_{1} \pi_{\mathrm{t}-1}+\alpha_{2} \Pi_{\mathrm{t}-1}+\beta^{\prime} \mathrm{y}_{\mathrm{t}-1}+\gamma^{\prime} \mathrm{e}_{\mathrm{t}-1}+\delta^{\prime}+\varepsilon_{\mathrm{t}} \\
& 0 \leq \alpha_{1}=\alpha+\mu-\alpha \mu \leq 1 ; 0 \leq \alpha_{2}=\left(1-\alpha_{1}\right) \nu \leq 1 ; \quad \beta^{\prime}=\beta \kappa ; \\
& \gamma^{\prime}=\gamma \lambda ; \quad \delta^{\prime}=\delta+\beta(1-\kappa) \overline{\mathrm{y}}+\gamma(1-\lambda) \overline{\mathrm{e}}+\left(1-\alpha_{1}\right)(1-v) \Pi^{*}
\end{aligned}
$$

From the parameter restrictions, it follows that $\alpha_{1}+\alpha_{2} \leq 1$. The larger $\alpha_{1}$ (hence, the smaller $\alpha_{2}$ ) and the smaller $\gamma^{\prime}$ (in absolute value) are, the more

\footnotetext{
${ }^{2}$ We have explored more complicated schemes by adding several lagged difference terms to the equations $\left(\Delta \mathrm{y}_{\mathrm{t}-\mathrm{i}}\right.$ and $\Delta \mathrm{e}_{\mathrm{t}-\mathrm{i}}$ respectively), but on the whole, this gave inferior estimation results.
} 
persistent domestic inflation is, and the longer it takes until the country's price competitiveness is at par vis-a-vis other member states after it has been hit by an asymmetric supply shock ( $\varepsilon$ ). Thus, the estimates of $\alpha_{1}, \alpha_{2}$ and $\gamma^{\prime}$, taken in conjunction, tell us to what extent national economies in EMU have really integrated. Incidentally, the significance of the domestic output gap (i.e., the parameter $\beta^{\prime}$ ) is also indicative of the degree of economic regionalism in inflation dynamics.

\section{Data issues}

We have obtained quarterly data from Datastream, covering the period 1980-2000, for France, Germany, Italy, the Netherlands and Spain. Lack of consistent data over a sufficiently long period prevented us from considering other member states of EMU as well. Inflation in the euro area is a weighted average of the gdp-deflators for the constituent countries, with the euro area prior to the establishment of EMU represented by the group of countries participating in the European Exchange Rate Mechanism. ${ }^{3}$ We have experimented with several indicators of the output gap: deviations of real gdp from trend, constructed by a $\operatorname{HP}(1600)$ filter, the rate of capacity utilization, the unemployment rate and its inverse. The last proxy, implying a hyperbolic Phillips curve, turned out to be superior throughout the sample of countries. Forced by the (un)availability of data, we had to measure the real exchange rate in terms of either consumer price deflators or unit labour costs, where we would have preferred gdp-deflators.

Unit-root tests (both Augmented Dickey-Fuller and Phillips-Perron) showed for each country that all but one series are stationary. The exception is the real exchange rate based on unit labour costs, which led us to choose the real exchange rate based on consumer price deflators as our measure of international competitiveness. So, the preferred data set is consistent with

\footnotetext{
${ }^{3}$ The obvious alternative is to identify $\Pi$ prior to 1999 with German inflation, but this gave implausible estimation results.
} 
Svensson's (2001) prior that all variables in eq. (1) are stationary.

Studies by Gonenc et al. (2000) and Rich and Tracey (2000) suggest that the persistence of domestic inflation is not fully captured by simply including the quarterly lagged rate of inflation $\left(\pi_{t-1}\right)$ as a regressor. The reason is that wage developments (especially in Europe) are largely governed by collective labour agreements that are effective during a relatively long period of time. Following Rudebusch (2000), we have experimented with more complicated lag structures, and established that using lags of up to and including eight quarters fits best for the countries considered. ${ }^{4}$ This confirms the notion of Fuhrer and Moore (1995), elaborating on Taylor (1980), that wage inertia extending over several quarters tend to translate into equally severe inflation persistence.

\section{Estimation results}

Eq. (7) was fitted over the entire sample period (1980-2000) and over the subperiod 1990-2000, for each country separately and for a panel of the five countries. We used OLS (and SUR for the panels), with the covariance matrix estimated by the method suggested by Newey and West (1987) to allow for $\mathrm{ARCH}$ effects found in some equations. The results are recorded in table 1 , together with some summary statistics.

As it turns out, inflation in most countries considered is primarily driven by past inflation rates, with the real exchange rate playing a very limited role (if any). This conclusion holds for both sample periods. ${ }^{5}$ As revealed by the results of the pooled regressions (with only $\delta^{\prime}$ allowed to vary across countries), the pass-through of changes in the real exchange rate to domestic inflation has even declined over time (though not significantly). Recent research by Taylor (2000) and others (Choudry and Hakura, 2001; Gagnon and Ihrig, 2001) suggests that this is due to a shift towards an environment of

\footnotetext{
${ }^{4}$ All pre-testing results are available from the authors upon request.

${ }^{5}$ In the longer sample, $\gamma^{\prime}$ is significant for France, but it has the wrong sign.
} 
lower inflation, whether or not induced by monetary policy. The argument runs as follows. The extent to which firms pass through cost increases as well as price increases at competing firms depends on their expectations about the persistence of such increases. This perceived persistence is associated with the overall level of inflation, which is assumed to be indicative of the pricing power of firms. And indeed, as appears from the last column of table 1, average inflation has decreased markedly in most countries considered. Moreover, we find that the influence of domestic demand pressure on inflation (i.e., the parameter $\beta^{\prime}$ ) has declined significantly over the years in France, Italy and the Netherlands, which also supports Taylor's hypothesis. Remarkably, this is not revealed by the results of the pooled regressions, suggesting that the assumption of constant slope coefficients across countries is not entirely appropriate. It follows that national economies in EMU are not perfectly integrated as regards price (and wage) formation, which corroborates recent findings by Aksoy et al. (2002) and Fase (2002).

Notwithstanding this last conclusion, inflationary expectations in some countries - Germany in particular — were based more and more on average European inflation as EMU got nearer. This emerges from a comparison of the estimates of $\alpha_{1}$ and $\alpha_{2}$ between the two samples. ${ }^{6}$ Spain is found to be most oriented towards Europe in this regard, already from the 1980s onward, which is probably due to the fact that this country has the strongest trade links with the rest of the euro area. Inflation persistence in France and Italy has remained considerable through the years. It is beyond the scope of this paper to go deeply into the possible causes behind this finding. We do note, however, that those countries have the highest scores on product market regulation in our sample, according to a recent study by the OECD (Nicoletti et al., 2001, pp. 43-44). This may have a bearing on the viability of indexation and, hence, on price staggering. The Netherlands, on the other

\footnotetext{
${ }^{6}$ Although the sum of these parameters exceeds unity in some cases, thereby breaching the theoretical restriction, it does only significantly so in the case of Spain in the longer sample (according to a Wald test). Furthermore, we had to reject the hypothesis that $v$ in eq. (6) is uniform across countries.
} 
hand, seems to have moved towards pretty sound inflation dynamics. The most recent estimates of $\alpha_{1}$ and $\alpha_{2}$ for the Netherlands imply that Dutch inflation is largely governed by the perception of medium-term price stability in the euro area (i.e., by $\Pi^{*}$ ). Hence, the effects of exogenous price shocks on inflation tend to be short-lived in the Netherlands.

\section{Concluding remarks}

This study was primarily inspired by curiosity about the degree and speed of price level convergence across EMU, after a member state has been hit by an asymmetric supply shock. Our finding that regional inflation rates in the euro area are not significantly affected by deviations of real exchange rates from their steady-state levels does not bode well for a spontaneous let alone rapid - convergence. It follows that stationarity of real exchange rates in our sample of countries is conditional on the possibility of adjustments in nominal exchange rates. Since this flexibility does not exist within EMU, differences in price competitiveness between member states may last for quite a long time. This is the more so as there are still marked differences in inflationary dynamics - hence, in the propagation of shocks - between member states of EMU, which further complicate the pursuit of a common monetary policy. These findings lead us to conclude that the euro area is not an optimal currency area yet, lending support to the quest for continued structural reforms in European labour and product markets. ${ }^{7}$

We acknowledge that our findings are based on a simple model of inflation dynamics, especially where the formation of expectations is concerned. The results are also prone to the Lucas critique. Indeed, the empirical evidence produced in this paper supports the view of Taylor (2000) and others that the inflationary environment tends to alter the shape of the Phillips curve. It may well be, therefore, that the influence of real exchange rates (and other factors) on regional inflation levels will increase in the unlikely

\footnotetext{
${ }^{7}$ See Hughes Hallett and Weymark (2001) for a theoretical underpinning of this proposition.
} 
event that the euro area runs into persistently higher inflation zones. 


\section{Literature}

Aksoy, Y., De Grauwe, P. and Dewachter, H. (2002). 'Do Asymmetries Matter for European Monetary Policy?', European Economic Review, vol. 46, pp. 443469.

Choudri, E.U. and Hakura, D.S. (2001). 'Exchange Rate Pass-Through to Domestic Prices: Does the Inflationary Environment Matter?', IMF Working Paper WP/01/194.

Fase, M.M.G. (2002), 'Inflation Differentials and their Convergence in EMU', De Economist, vol. 150, pp. 211-217.

Fuhrer, J.C. and Moore, G.R. (1995). 'Monetary Policy Trade-Offs and the Correlation between Nominal Interest Rates and Real Output', The American Economic Review, vol. 85, pp. 219-239.

Gagnon, J.E. and Ihrig, J. (2001). 'Monetary Policy and Exchange Rate PassThrough', International Finance Discussion Papers, No. 704, Board of Governors of the Federal Reserve System (www.federalreserve.gov/pubs/ ifdp).

Gonenc, R., Maher, M. and Nicoletti, G. (2000). 'The Implementation and the Effects of Regulatory Reform: Past Experience and Current Issues', OECD Working Paper, No. 251, OECD, Paris (http://www.oecd.org/eco).

Hughes Hallett, A. and Weymark, D.N. (2001). 'The Cost of Heterogeneity in a Monetary Union', Working Paper, No. 01-W28, Department of Economics, Vanderbilt University, Nashville (www.vanderbilt.edu/econ).

Leitemo, K. and Söderström, U. (2001). 'Simple Monetary Policy Rules and Exchange Rate Uncertainty', Working Paper, Norges Bank and Sveriges Riksbank.

Newey, W.K. and West, K.D. (1987). 'A Simple, Positive Semi-Definite, Heteroskedasticity and Autocorrelation Consistent Covariance Matrix', Econometrica, vol. 55, pp. 703-708.

Nicoletti, G., Bassanini, A., Ernst, E., Jean, S., Santiago, P. and Swaim, P. (2001). 'Product and Labour Markets Interactions in OECD Countries', OECD Working Paper, No. 312, OECD, Paris (http://www.oecd.org/eco).

Rich, R. and Tracey, J. (2000). 'Uncertainty and Labor Contract Durations', NBER Working Paper, No. 7731, NBER, Cambridge (MA) (http://www. nber.org/papers/w7731).

Rudebusch, G.D. (2000). 'Assessing Nominal Income Rules for Monetary Policy with Model and Data Uncertainty', Working Paper, Federal Reserve Bank of San Francisco (www.sf.frb.org/econrsrch/economists/grudebusch.html).

Svensson, L.E.O. (1998). 'Open-Economy Inflation Targeting', Working Paper, Institute for International Economic Studies (http:\% www.iies.su.se\% leosven).

Svensson, L.E.O. (2001). 'The Zero-Bound in an Open Economy: A Foolproof Way of Escaping from a Liquidity Trap', Monetary and Economic Studies, Special Issue, Bank of Japan, pp. 277-312.

Taylor, J.B. (1980). 'Aggregate Dynamics and Staggered Contracts', Journal of Political Economy, vol. 88, pp. 1-23.

Taylor, J.B. (2000). 'Low Inflation, Pass-Through, and the Pricing Power of Firms', European Economic Review, vol. 44, pp. 1389-1408. 
Table 1

Estimation results ${ }^{\mathrm{a}}$

\begin{tabular}{|c|c|c|c|c|c|c|c|c|}
\hline & $\alpha_{1}$ & $\alpha_{2}$ & $\beta^{\prime}$ & $\gamma^{\prime}$ & $\delta^{\prime}$ & $\overline{\mathrm{R}}^{2}$ & $\overline{\mathrm{S}_{\mathrm{e}}}$ & $\bar{\pi}$ \\
\hline \multicolumn{9}{|c|}{ Sample 1980-2000 } \\
\hline France & $\begin{array}{c}0.90 \\
(20.3)\end{array}$ & $\begin{array}{l}0.02 \\
(0.4)\end{array}$ & $\begin{array}{l}0.11 \\
(2.2)\end{array}$ & $\begin{array}{l}0.03 \\
(1.9)\end{array}$ & $\begin{array}{c}-3.83 \\
(2.7)\end{array}$ & 0.98 & 0.51 & 3.89 \\
\hline Germany & $\begin{array}{l}0.78 \\
(8.7)\end{array}$ & $\begin{array}{l}0.09 \\
(1.2)\end{array}$ & $\begin{array}{l}0.03 \\
(1.6)\end{array}$ & $\begin{array}{c}-0.00 \\
(0.1)\end{array}$ & $\begin{array}{c}-0.04 \\
(0.0)\end{array}$ & 0.91 & 0.47 & 2.44 \\
\hline Italy & $\begin{array}{c}0.94 \\
(15.7)\end{array}$ & $\begin{array}{c}-0.01 \\
(0.1)\end{array}$ & $\begin{array}{l}0.28 \\
(2.1)\end{array}$ & $\begin{array}{c}-0.00 \\
(0.2)\end{array}$ & $\begin{array}{c}-1.89 \\
(0.8)\end{array}$ & 0.98 & 0.80 & 7.33 \\
\hline Netherlands & $\begin{array}{l}0.76 \\
(6.7)\end{array}$ & $\begin{array}{l}0.11 \\
(1.5)\end{array}$ & $\begin{array}{l}0.05 \\
(3.4)\end{array}$ & $\begin{array}{c}-0.02 \\
(0.6)\end{array}$ & $\begin{array}{l}0.85 \\
(0.3)\end{array}$ & 0.78 & 0.80 & 2.06 \\
\hline Spain & $\begin{array}{l}0.51 \\
(3.8)\end{array}$ & $\begin{array}{l}0.80 \\
(3.3)\end{array}$ & $\begin{array}{l}0.28 \\
(1.3)\end{array}$ & $\begin{array}{c}-0.04 \\
(1.6)\end{array}$ & $\begin{array}{l}2.63 \\
(0.9)\end{array}$ & 0.85 & 1.21 & 6.80 \\
\hline Pooled & $\begin{array}{c}0.91 \\
(52.2)\end{array}$ & $\begin{array}{l}\mathbf{0 . 0 8} \\
(\mathbf{3 . 0})\end{array}$ & $\begin{array}{l}0.02 \\
(2.6)\end{array}$ & $\begin{array}{l}-0.01 \\
(1.5)\end{array}$ & $-b$ & 0.96 & 0.86 & 4.75 \\
\hline \multicolumn{9}{|c|}{ Sample 1990-2000 } \\
\hline France & $\begin{array}{l}0.87 \\
(3.5)\end{array}$ & $\begin{array}{l}0.00 \\
(0.0)\end{array}$ & $\begin{array}{l}0.07 \\
(1.0)\end{array}$ & $\begin{array}{l}0.02 \\
(0.5)\end{array}$ & $\begin{array}{c}-2.14 \\
(0.6)\end{array}$ & 0.87 & 0.32 & 1.67 \\
\hline Germany & $\begin{array}{l}0.57 \\
(5.2)\end{array}$ & $\begin{array}{l}0.47 \\
(2.8)\end{array}$ & $\begin{array}{l}0.02 \\
(0.3)\end{array}$ & $\begin{array}{l}0.03 \\
(1.2)\end{array}$ & $\begin{array}{c}-3.09 \\
(1.3)\end{array}$ & 0.92 & 0.48 & 2.17 \\
\hline Italy & $\begin{array}{l}0.91 \\
(8.7)\end{array}$ & $\begin{array}{l}0.27 \\
(1.1)\end{array}$ & $\begin{array}{c}-0.19 \\
(0.8)\end{array}$ & $\begin{array}{c}-0.02 \\
(0.9)\end{array}$ & $\begin{array}{l}3.93 \\
(1.0)\end{array}$ & 0.91 & 0.67 & 4.29 \\
\hline Netherlands & $\begin{array}{l}0.14 \\
(0.8)\end{array}$ & $\begin{array}{l}0.14 \\
(2.5)\end{array}$ & $\begin{array}{l}0.02 \\
(1.4)\end{array}$ & $\begin{array}{l}-0.05 \\
(1.6)\end{array}$ & $\begin{array}{l}5.65 \\
(1.9)\end{array}$ & 0.55 & 0.43 & 2.12 \\
\hline Spain & $\begin{array}{l}0.42 \\
(1.4)\end{array}$ & $\begin{array}{l}0.81 \\
(2.0)\end{array}$ & $\begin{array}{l}0.31 \\
(1.0)\end{array}$ & $\begin{array}{c}-0.03 \\
(0.7)\end{array}$ & $\begin{array}{l}2.04 \\
(0.4)\end{array}$ & 0.63 & 1.25 & 4.45 \\
\hline Pooled & $\begin{array}{c}0.72 \\
(12.8)\end{array}$ & $\begin{array}{l}0.23 \\
(6.0)\end{array}$ & $\begin{array}{l}0.03 \\
(2.6)\end{array}$ & $\begin{array}{l}0.00 \\
(0.2)\end{array}$ & $-c^{c}$ & 0.84 & 0.80 & 2.94 \\
\hline
\end{tabular}

a T-ratios in brackets; $\overline{\mathrm{R}}^{2}$ is the coefficient of determination and $\overline{\mathrm{S}}_{\mathrm{e}}$ is the standard error of estimate, both adjusted for degrees of freedom; $\bar{\pi}$ is the sample mean of gdp-inflation.

${ }^{\mathrm{b}}$ Varies across countries (Fr: 0.65; Ge: 0.41; It: 1.10; Nl: 0.42: Sp: 0.99).

${ }^{c}$ Varies across countries (Fr: -0.61; Ge: -0.58; It: 0.07; Nl: -0.70: Sp: 0.26). 